\title{
Business Incubator and Its Impact on Business Success: A Case Study of Jordan Enterprise Development Corporation (JEDCO)
}

\author{
Rula Ali Al-Damen ${ }^{1}$ \\ ${ }^{1}$ Amman Arab University, Amma, Jordan \\ Correspondence: Rula Ali Al-Damen, Amman Arab University, Amma, Jordan. E-mail: \\ aldamenrula@yahoo.com
}

Received: November 27, 2020

Accepted: December 30, 2020 Online Published: January 4, 2021

doi:10.5539/jms.v11n1p35

URL: https://doi.org/10.5539/jms.v11n1p35

\begin{abstract}
This study aimed to identify the level of services provided by the business incubators and their impact on business success. The sample for the field study consisted of 30 businesses that benefited from business incubator services at Jordan Enterprise Development Corporation (JEDICO). Various techniques, such as descriptive and analytical methods, were utilized in the study to test the hypotheses. The results demonstrated that beneficiaries perceived business incubators' support practices as high level and that there was a statistically significant impact of business incubators on business success where the networking support services dimension had the highest influence on business success, followed by infrastructure support services. As a result of the findings, the study has provided a set of recommendations.
\end{abstract}

Keywords: business incubator, business success, beneficiary, JEDICO, JIC

\section{Introduction}

Interests in entrepreneurial and small businesses have been increasing day after day. Micro, small, and medium-sized enterprises are still considered the most prevalent active economic force globally and in the Arab world. In Jordan, the economy relies significantly on small and medium-sized companies to bolster its economy. MSEs constitute $98 \%$ of all enterprises in the country, two-thirds of which have less than 19 employees and employ over $60 \%$ of the Jordanian workforce (JEDICO website). The concept and practice of business incubation (BI) were established in the advanced countries some 50 years ago. Since the Batavia Industrial Centre in New York in 1959, the idea and its implementation into physical infrastructure quickly took root in the United States, and then internationally. In Jordan, the emergence of business incubators has recently unfolded. Following the example of developed countries, many universities and industrial cities in Jordan developed several incubators looking to encourage entrepreneurship and innovation in Jordanian society.

One active player in the development and growth of SMEs in Jordan is the Jordan Enterprise Development Corporation (JEDCO). It is a governmental organization, financially and administratively autonomous, with a board of directors that is chaired by the Minister of Industry and Trade and whose members represent an equal number of the private sector and public sector stakeholders. JEDCO seeks to promote the culture and actions of innovative entrepreneurship, facilitate the creation of pipeline and innovative businesses via special start-ups and incubation support activities implemented with other public and private sector hosts under the national umbrella of the Jordan Innovation Centers Network (JIC). In 2005, the Jordan Enterprise Development Corporation (JEDCO), in collaboration with some government and private entities, established the Network of Networks and Centers (JIC), which consists of 5 centers in Irbid, Karak, Madaba, Jerash, Ajloun and Mafraq and three liaison offices in (Ma'an, Tafila, and Wadi Musa). In the period between 2005-2015, JEDICO businesses incubators hosted 112 different projects in its different centers (Aridi, 2015).

\subsection{Objectives of the Study}

The objectives of this study are to:

- Identify the level of business incubators services provided by the beneficiary (tenants and graduated) firms' perspective.

- Identify the level of business success from the beneficiary (tenants and graduated) firms' perspective. 
- Investigate the impact of business incubator services (infrastructure, services, business support, and mediation supports) on business success from the beneficiary firms' perspective.

- Highlight the most important dimensions of business incubator services that affect the business's success.

\subsection{Problem Statement and Its Elements}

It seems that micro and small businesses play a major role in almost all economies, whether in developed or developing countries including Jordan. According to a pilot study done by the researcher, it was found that there are many decisive views on the level of services provided in the business incubators in Jordan and their role in the development and success of beneficiary (tenants and graduated) firms. This motivates the researcher to identify the level of services provided by the business incubators and their impact on business success from a beneficiary perspective.

Research questions that guided this study include:

1) What is the level of services provided by the business incubator at JEDICO from the beneficiary perspective?

2) What is the level of business success from the beneficiary perspective?

3) What is the impact of a business incubator on business success from the beneficiary (tenants and graduated) firms' perspective?

\subsection{Research Hypothesis}

(H01): There is no significant impact at the level of $(\alpha \leq 0.05)$ of business incubator services (infrastructure, services, business support, and networking supports) on the Business success (revenue growth, job creation)

The research sub-hypothesis

(H0.1.1): There is no significant impact at the level of $(\alpha \leq 0.05)$ of business incubator services on Business income growth

(H0.1.2): There is no significant impact at the level of $(\alpha \leq 0.05)$ of business incubator services on Business employment growth

\subsection{The Study Model}

The research model was developed by the researcher based on previous studies (Wiggins \& Gibson, 2003; Peters et al., 2004; Ratinho et al., 2009; Hackett \& Dilts, 2004; Fadahunsi, 2012). The Independent variable of this study includes three business incubator support services (Infrastructure support, Business support, and networking support). The dependent variable is a Business success: it includes two elements (revenue growth and Job creation). The research framework can be seen below;

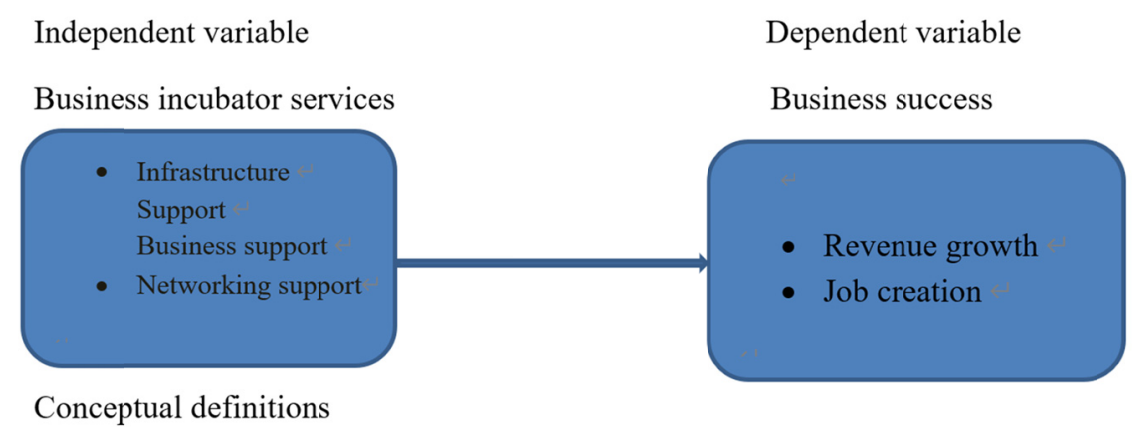

Figure 1. The conceptual model of the research

Business Incubator: a facility that is specifically developed to advance the growth and success of new ventures through a range of supporting resources including infrastructure, business support services, and networking supports in an atmosphere conducive to new venture development, survival, and early-stage growth.

Business success: the ability of a business to contribute to jobs and wealth creation through business start-up, survival, and growth. Success will be measured in terms of growth in revenue and creating jobs.

Infrastructure services: providing incubated firms with appropriate space, furniture, conference rooms, and secretarial services (photocopying, receiving, filing, faxing, Internet, receiving and organizing correspondence, 
telephone calls, etc.).

Business support services: supporting incubated firms with preparing business plans, mentors, entrepreneurial lessons and business development advice, consultancy and other services concerned with business and legal matters, human resources and marketing issues such as staffing, advertising, and financial assistance

networking support services: Supporting incubated firms through creating a network of individuals and organizations and acting as an intermediary or mediator between incubates and external parties including universities, industry contacts, funding institutions, and professional services providers such as lawyers, accountants, consultants, marketing specialists, venture capitalists, angel investors, and volunteers

Beneficiary firms: Those firms that are now benefiting or have spent certain periods in business incubators and benefited from the services, facilities and support needed by incubator and achieved the objectives that were difficult to achieve without the care of business incubators.

\section{Theoretical Background}

\subsection{Definition of Business Incubators (BIs)}

The term Business incubator has been a common subject among different researchers (Hackett \& Dilts, 2004; Campbell, 1989; Petree, 1997; Mubaraki, 2013) and institutions (National Business Incubation Association (NBIA); European Commission, 2002). It is clear that various BIs definitions focus on two essential aspects: the actual definition (what it is) and implicit impacts (effects) BIs have in firms, communities, and science \& technology. However, there is still no single agreed-upon definition of business incubation and incubator.

Hackett and Dilts (2004) in their comprehensive BI research overview, offer that a "business incubator is a "a shared office space facility that seeks to provide its incubates (i.e., "portfolio-" or "client-" or "tenant-companies") with a strategic, value-adding intervention system (i.e., business incubation) of monitoring and business assistance"

According to Hughes and Morgan (2007), business incubator is "a facility that houses young, small firms to help them develop quickly into competitive business". Duff further suggests that a business incubator is "an organization which offers a range of business development services and access to small space on flexible terms, to meet the needs of new firms. The package of services offered by a business incubator is designed to enhance the success and growth rates of new enterprises thus maximizing their impact on economic development".

Payton (2012) has offered a definition of a business incubator as "a program designed to provide support to new businesses to help them succeed. Every incubator program is different, but incubators and accelerators typically include access to mentors or experts from different areas of business (finance, marketing, and management, for example) that guide the startup".

Vasily Ryzhonkov (2012) defined a business incubator as "a supporting system for a startup (a target system) which "moves" it from point A (idea) to point B (successful venture) using special practices (services) along the life cycle".

National Business Incubation Association (NBIA) of the United States of America may have their own business incubation definition, such as: "Business incubators nurture the development of entrepreneurial companies, helping them survive and grow during the start-up period when they are most vulnerable. Their programs provide client companies with business support services and resources tailored to young firms".

According to European Commission (2002), business incubators are organizations that assist with the creation of successful enterprises by providing them with a vast amount of support, including: incubator space, business support services, and clustering and networking opportunities.

The business incubator is a physical space or facility that accommodates a business incubation process. In this research, a business incubator is seen as a facility that is specifically designed to help the growth and success of new ventures through a range of supporting resources and services including infrastructure, business support services, and mediation supports in an atmosphere conducive to new venture development, survival, and early-stage growth.

\section{Services provided by business incubators}

Considering the importance of business incubators for individuals and economies, a great emphasis has been attached on services provided by them (Wiggins \& Gibson, 2003). It can be said that business incubators of all kinds are service organizations, regardless of their type of facilities and services provided by them.

Many researchers have established classifications of services that should be offered by every incubator (Wiggins 
\& Gibson, 2003; Peters et al., 2004; Carayannis \& von Zedtwitz, 2005; Chandra, 2007; Bergek \& Norrman, 2008; Ratinho et al., 2009).

Wiggins and Gibson (2003) identified the following three components that should be provided by business incubators for tenants: Strategic services, Operational and Infrastructure services. Peters et al. (2004) identified three shared services (i) infrastructure, (ii) coaching, and (iii) networking. Moreover, Carayannis and von Zedtwitz (2005) proposed five services, these were access to physical resources, office support, access to financial resources, entrepreneurial startup support, and the provision of professional services.

Bergek and Norrman (2008) cited in Gerlach (2015) created a 'best practice framework' that can serve as a basis for identifying best practice incubator models and for more rigorous evaluations of incubator performance. In their article, they pointed out four components that have received particular attention in the most important prevailing scientific articles when it comes to the services of an incubator. A similar review was also done by Ratinho et al. (2009), resulting in the same four components. These four are: the shared office space and shared resources, the business support services, and access to networks.

Despite the variations, this study will focus on the following services within the business incubator.

1) Infrastructure: Including fully equipped office with a personal computer, scanners, projectors, LCDs and smart boards, a meeting room, communications services (Internet, phone, address), and secretarial services.

2) Business support services: incubator provides a wide range of free consultations on the following:

- Preparing business plans,

- Entrepreneurial training and business advice,

- Consultancy and associated services concerned with general business and legal services (drafting contracts with local and national suppliers or customers; to promote export; employment contracts and the drafting contracts in foreign languages) and financial assistance

- Human resources and marketing services such as staffing, advertising.

3) Networking services: The Incubator provides technical support and advice to tenants to make the project succeed. The Incubator makes contact with donors and supporters to provide financial support for the project supporting incubated firms through creating a network of individuals and organizations and acting as a mediator between incubates and different parties.

\subsection{Business Success}

From the literature review, it seems that there is neither a unified definition regarding micro and small business success nor success measures. Attempts have been made to define the concept.

Business success is defined as the ability of the business to achieve its stated goal. According to Lucky (2011), business success provides insightful information on efficiency, growth, profit, size, liquidity, success/failure, market share, and leverage. It supplies information about the business' growth, success/failure, and most predominantly, the profitability of the business. Therefore, business success demonstrates that the business is profitable, effective, efficient, and successful.

In academic and practitioner publications, there is no standard measure for assessing micro and small firm's success. Various measures (financial and non-financial) were used in empirical researches on assessing the micro and small firm's success. Financial and non-financial measures of success include but are not limited to profitability, total assets, return on investment (ROI), sales volume, employment size, capital employed, market share, customer satisfaction, productivity, turnover, delivery time, employee turnover, and others. The firm's employment and annual sales growth was generally the most accepted method of measuring growth within these studies (Hackett \& Dilts, 2004; Fadahunsi, 2012). However, other researchers have found that there are other factors that owners use to assess the success of their businesses (Simpson et al., 2004; Walker \& Brown, 2004; Getz \& Carlsen, 2000; Reijonen \& Komppula, 2007; Reijonen, 2008; Niehm et al., 2008). Among the factors of success used by owners were: a sense of achievement, a sense of pride, being one's own boss, contributing to the welfare of the community, customer and client satisfaction, earning a living, having a quality product, lifestyle, personal satisfaction, recognition by others, running a successful business, staff satisfaction, teamwork and the children wanting to be part of the business Vilkinas et al. (2011).

In this study, business success will be measured by using revenue growth and job creation.

\subsection{Previous Studies}

Li, Cali and et al. (2020). The study aimed to examine the role of business incubators in providing greater 
services (networking services, capital support, and training programs) in entrepreneurship development and examines the mediating and moderating role of business start-ups and government regulations for entrepreneurship in Pakistan. The sample consisted of $567 \mathrm{men}$ and women living in five provinces of Pakistan. The study found that business incubators are playing an effective mediating role in providing networking services, capital support, and training programs for individuals and entrepreneurs which are significant for entrepreneurship development, and government regulations for entrepreneurship have a positive moderating effect between business start-up and entrepreneurship development

Mumtaz et al. (2017) proved in their study that technology business incubation centers were established in five different universities that are running the business incubation centers in their universities. LUMS Center of Entrepreneurship, COMSATS Incubation Center, University of Engineering and Technology—Peshawar, TIC-NUST University and Punjab University Incubation Center of Pakistan. These incubators demonstrated their role at the universities to cultivate the entrepreneurial culture and providing support to startups and tenant firms provided with the opportunity to learn from multipurpose experiences of big industry icons by arranging informative workshops and seminars.

Puķīe and Geipele (2015) studied business incubators as a financial tool for new business development in Latvia. The results can be assessed as positive and the research hypothesis has been confirmed-business incubator support gives an entrepreneur development opportunity when starting a new business. The overall conclusion is that business incubators as a tool of regional development in Latvia operate successfully.

Şehitoğlu and Özdemir (2013), the result demonstrates that the services provided by the Technology Business Incubation model of Turkey (TEKMERs) have a positive impact on the firm performance during the post-graduation period

Dee et al. (2012) reviewed literature released by the academic and practitioner communities both quantitatively and qualitatively regarding the role and success of business incubation in supporting start-ups with high-growth potential. The result indicated that in academic and practitioner publications alike there is no standard recommendations/measures for analyzing incubator performance and research on business incubation needs to be considered in the context of other bodies of knowledge; specifically related to cluster theory, regional innovation systems, entrepreneurship, investment, and firm growth.

In the Arabic context, there are a lot of studies that investigated the topic of business incubators and their impact on the success of small businesses.

Badandy (2018) examined the impact of innovation on the success of entrepreneurial enterprises in incubators at King Hussein Business Park (KHBP). The target population of this study is composed of 30 entrepreneurial enterprises in incubators at KHBP. The findings of the current study indicated that innovation plays a vital role in the success of entrepreneurial enterprises (growth, learning, and goal attainment) in business incubators at KHBP.

Barhoom (2015) study aimed at identifying the effectiveness of business incubators as a tool to solve the problem of unemployment among the youth and, especially entrepreneurs by turning their creative ideas into successful income-generating projects through studying the case of Business and Technology Incubator and Technology at the Islamic University of Gaza within the two projects (Initiators project—Spark project). The show the level of providing services from Business and Technology Incubator and Technology was average to somewhat whereas this level went down after graduation

Al-Mubaraki and Busler (2013) found that business incubators in developing countries provide support for start-up companies and graduated companies tend to have a greater probability of success and have a significant positive impact on economic development.

AlWadi (2010) discussed the rationale for the adoption of incubators in developing countries and assess their performance in seven dimensions: finance, services provided the freedom to enter and exit, incubator management, and role of government, the role of the university and the culture of the institutional environment. The researcher found that the assessment of projects for the incubators in Jordan has been given to the overall average indicators which were at a modest level. The study also showed that the confidence in the role of the university projects was high, while confidence in the role of institutional environment culture in the development of incubators has been weak.

\section{Research Methodology}

The research design for testing the conceptual model of this research was quantitative and explanatory. 
The case study was conducted at JEDICO. It is aimed at investigating the impact of business incubators on the success of incubated/graduated firms that benefited from JEDICO Business Incubators. The unit of analysis was the owners/managers of beneficiary firms

The data of the study were collected in the period between from February 2016 to June 2017 through two main sources, which are, secondary sources which have been gathered from books, periodical journals, and World Wide Web (Internet) and primary sources where the questionnaire technique was developed to reflect the study objectives and questions.

The research surveyed the graduate and tenant enterprises owners from different JEDICO business incubators under the national umbrella of the Jordan Innovation Centers Network (JICs). Questionnaires were distributed to all beneficiary firms through different JEDICO Business Incubation officers in all governorates. Only 30 questionnaires were received and analyzed.

The questionnaire included three parts. The first aimed at collecting demographic data around the sample, such as information about, their age, educational level, work experience.

Part two included information on the independent variable related to business incubators services components (Strategic support, Operational support, Infrastructure support).

Part three included questions regarding the dependent variable related to business success included (Revenue growth and Job creation)

A five-point Likert type scale was used as follows: 1 (strongly disagree), 2 (disagree), 3 (Neutral), 4 (Agree), and 5 (strongly agree). An interval class was created to assess the results of the study as follows: (1) low; 1 to 2.33 , (2) medium; 2.34 to 3.66 , and (3) high; 3.67 to 5.00 . Validity of the questionnaire was checked through a panel of referees; academic and professional experts with high professional backgrounds

Cronbach Alpha test was used to test the reliability of the questionnaire statements. The results of Cronbach Alpha as shown in Table 1 were between 0.852 and 0.972, which is an acceptable value in this test (more than .7 is accepted) which indicates that all questionnaire statements are appropriate for this study. Thereby, these results indicate the high statistical reliability of the questionnaire.

Table 1. Reliability results

\begin{tabular}{lll}
\hline Variable & No of Items & Cronbach's Alpha \\
\hline Business Incubator services & & \\
Infrastructure support & 6 & 0.901 \\
Service support & 9 & 0.833 \\
Mediation support & 6 & 0.812 \\
Total & 21 & 0.848 \\
Business Success & & \\
Job creation & 3 & 0.798 \\
Revenue growth & 3 & 0.841 \\
Total & 6 & 0.819 \\
\hline
\end{tabular}

\section{Results Analysis}

\subsection{Research Sample Characteristics}

As seen in Table 2, most of the sample is male 63.3\%, the average age of respondents is from 30-39 years, $36.6 \%$ with average years of work experience ranging between 9-12 years. Almost half of the respondents hold a diploma degree (53.7\%), most of the business type (63.6\%) is an industrial type. 
Table 2. Sample demographic characteristics

\begin{tabular}{|c|c|c|c|}
\hline & & Frequency & Percent \\
\hline \multirow[t]{3}{*}{ Sex } & male & 19 & 63.3 \\
\hline & female & 11 & 36.7 \\
\hline & Total & 30 & $100 \%$ \\
\hline \multirow[t]{5}{*}{ Age } & $20-29$ & 7 & 23.4 \\
\hline & $30-39$ & 13 & 43.3 \\
\hline & $40-49$ & 6 & 20.0 \\
\hline & 50 and above & 4 & 13.3 \\
\hline & Total & 30 & $100 \%$ \\
\hline \multirow[t]{4}{*}{ Education } & diploma & 16 & 53.4 \\
\hline & $\mathrm{BSc}$ & 8 & 26.6 \\
\hline & post & 6 & 20.0 \\
\hline & Total & 30 & $100 \%$ \\
\hline \multirow[t]{5}{*}{ Experience } & less than 4 years & 4 & 13.3 \\
\hline & $4-8$ & 7 & 23.4 \\
\hline & $9-12$ & 13 & 43.3 \\
\hline & 13 and above & 6 & 20.0 \\
\hline & Total & 30 & $100 \%$ \\
\hline \multirow[t]{4}{*}{ duration } & less than 3 years & 11 & 36.7 \\
\hline & $3-5$ & 4 & 13.3 \\
\hline & more than 5 & 15 & 50.0 \\
\hline & Total & 30 & $100 \%$ \\
\hline \multirow[t]{4}{*}{ Type } & industrial & 19 & 63.4 \\
\hline & service & 4 & 13.3 \\
\hline & technological & 7 & 23.3 \\
\hline & Total & 30 & $100 \%$ \\
\hline
\end{tabular}

\subsection{Descriptive Results}

In this part, the study represents the mean and standard deviation of the sample responses on the questionnaire's statements

As shown in Table 3, the respondents' perception of the level of business incubator services practices was high with an average mean 4.11 and average standard deviation 0.59 . The average mean was ranging from 3.98 to 4.34 , with a standard deviation that ranges from 0.55 to 0.66 .

The results for infrastructure support dimension indicated the highest category and first rank with a mean 4.34 and standard deviation 0.66; followed by business support services in the second rank with a mean 4.02 and standard deviation 0.58 and networking services dimension in the third rank with a mean 3.98 and standard deviation 0.55 . The above results indicated that the respondents perceived the JEDICO business incubator components are available at a high level at JEDICO business incubators. The majority of respondents agreed that the business incubators provide business support service infrastructures and networking support services at a high level.

\subsubsection{Independent Variables}

\subsubsection{Infrastructure Support Services}

Table 4 shows that the average mean of infrastructure variable items was 4.11 with a standard deviation of 0.59 which indicates that there is an agreement on the high existence of this variable. The average means of respondents' perception about the degree of existence of infrastructure services items were ranging from 4.06 to 4.40 , with a standard deviation that ranges from 0.49 to 0.95 . Such results indicate that there is an agreement on the high existence of infrastructure support variable items.

\subsubsection{Business Support Services}

Table 4 shows that the average mean of business support services variable items was 4.02 with a standard deviation of 0.58 which indicates that there is an agreement on the high existence of this variable. The average means of respondents' perception about the degree of existence of infrastructure services items were ranging from 3.38 to 4.40 , with a standard deviation that ranges from 0.49 to 0.55 . Such results indicate that there is an agreement on the high existence of business support variable items. 


\subsubsection{Networking (Mediation) Support Services}

Table 4 shows that the average mean of networking s support services variable items was 3.98 with standard deviation 0.55 which indicates that there is an agreement on high existence of this variable. The average means of respondents' perception about the degree of existence of networking support services items were ranging from 3.80 to 4.20 , with standard deviation that ranges from 0.44 to 0.69 . Such results indicate that there is an agreement on high existence of mediation support variable items.

\subsubsection{Dependent Variables Business Success}

As shown in Table 3, the respondents' perception about the level of business success was high with average mean 3.82 and average standard deviation 0.42. Average Mean was ranging from 3.98 to 4.34, with standard deviation that ranges from 0.39 to 0.44 . The results for Job creation dimension indicated high category and first rank with mean 3.84 and standard deviation 0.44 ; followed by revenue growth in the second rank with mean 3.79 and standard deviation 0.39 . The above results indicated that the respondents perceived a high level of business success variable items.

\subsubsection{Job Creation Variable}

Table 4 shows that the average mean of job creation variable items was 3.84 with standard deviation 0.44 which indicates that there is an agreement on high level of this variable. The average means of respondents' perception about the degree of level of job creation items were ranging from 3.66 to 4.00 , with standard deviation that ranges from 0.44 to 0.52 . Such results indicate that there is an agreement on high level of existence of job creation variable items.

\subsubsection{Revenue Growth}

Table 4 shows that the average mean of revenue growth variable items was 3.84 with standard deviation 0.44 which indicates that there is an agreement on high level of this variable. The average means of respondents' perception about the degree of level of job creation items were ranging from 3.73 to 3.86 , with standard deviation that ranges from 0.34 to 0.44 . Such results indicate that there is an agreement on high level of existence of revenue growth items.

The above result indicates that majority of respondents agreed that Business incubator contributed to an increase in their business income generation and job creation. Also, employees' number and revenue growth increases continuously with the increase in business time and size.

This above result is expected because JEDICO business incubation provides a high quantity and quality support services to all beneficiaries.

Table 3. Mean, standard deviation and rank for study variables

\begin{tabular}{|c|c|c|c|c|}
\hline & Variables & Mean & Standard deviation & Rank \\
\hline 1. & Business Incubator services & & & \\
\hline 1.1 & Infrastructure support & 4.34 & 0.66 & high \\
\hline 1.2 & Business support services & 4.02 & 0.58 & high \\
\hline \multirow[t]{2}{*}{1.3} & Networking services & 3.98 & 0.55 & high \\
\hline & Total & 4.11 & 0.59 & high \\
\hline 2. & Business success & & & \\
\hline 2.1 & Job creation & 3.84 & 0.44 & high \\
\hline \multirow[t]{2}{*}{2.2} & Revenue growth & 3.79 & 0.39 & high \\
\hline & Total & 3.82 & 0.42 & high \\
\hline
\end{tabular}


Table 4. Descriptive results (Business incubation Services and business success)

\begin{tabular}{|c|c|c|c|c|}
\hline \multicolumn{2}{|c|}{ To what extent do you think the incubator support the beneficiary businesses } & \multirow{2}{*}{$\begin{array}{l}\text { Mean } \\
4.40\end{array}$} & \multirow{2}{*}{$\begin{array}{l}\text { S.D } \\
0.49\end{array}$} & \multirow[t]{2}{*}{ Rank } \\
\hline 1. & Infrastructure support services & & & \\
\hline 1.1. & Working space & 4.20 & 0.76 & high \\
\hline 1.2. & Office furniture and equipment & 4. 33 & 0.95 & high \\
\hline 1.3. & Meeting rooms & 4.41 & 0.50 & high \\
\hline 1.4. & Physical safety and security & 4.26 & 0.69 & high \\
\hline 1.5 . & Secretarial and office services & 4.46 & 0.50 & high \\
\hline \multirow[t]{2}{*}{1.6.} & internet access, mail delivery and telephone service & 4.06 & 0.58 & high \\
\hline & Total & 4.34 & 0.66 & high \\
\hline 2. & Business support services & & & \\
\hline 2.1 & Business planning and forming a company & 4.40 & 0.49 & high \\
\hline 2.2 & financial/accounting management & 3.86 & 0.82 & high \\
\hline 2.3 & General Legal services & 3.86 & 0.62 & high \\
\hline 2.4 & human resources services & 3.80 & 0.55 & high \\
\hline 2.5 & marketing and sales services & 4.00 & 0.64 & high \\
\hline 2.6 & Training and development programs Training to develop business skills & 4.00 & 0.52 & high \\
\hline 2.7 & entrepreneurial development skills & 3.86 & 0.62 & high \\
\hline 2.8 & Mentoring \& Coaching programs & 4.20 & 0.55 & high \\
\hline \multirow[t]{3}{*}{2.9} & concentrate on product - business development & 4.26 & 0.49 & high \\
\hline & Advice on development of new products and services & & & \\
\hline & Total & 4.02 & 0.58 & high \\
\hline 3 & Networking support services & & & \\
\hline 3.1 & networks with entrepreneurial community & 3.93 & 0.69 & high \\
\hline 3.2 & Network with loans institutions & 4.20 & 0.55 & high \\
\hline 3.3 & Connects companies to advisory teams & 4.00 & 0.52 & high \\
\hline 3.4 & access to angel investors or venture capital & 3.80 & 0.55 & high \\
\hline 3.5 & Network with University resources and expertise & 3.93 & 0.58 & high \\
\hline \multirow{2}{*}{3.6} & Network with different Professionals & 4.06 & 0.44 & high \\
\hline & Total & 3.98 & 0.55 & \\
\hline 4. & Business success & & & \\
\hline 4.1 & Creating job & & & \\
\hline 4.1 .1 & Business incubator support contributed in business job creation growth & 4.00 & 0.52 & high \\
\hline 4.1 .2 & employees' number increases with the company age & 3.86 & 0.34 & high \\
\hline \multirow[t]{2}{*}{4.1 .3} & Number of employees increases continuously with the increase of business size & 3.66 & 0.47 & hgih \\
\hline & Total & 3.84 & 0.44 & \\
\hline 4.2 & Revenue growth & & & \\
\hline 4.2 .1 & Business incubator Helped in Company s surviving and growing & 3.73 & 0.44 & high \\
\hline 4.2 .2 & The growth in revenue increase continuously with time & 3.80 & 0.40 & high \\
\hline \multirow[t]{2}{*}{4.2 .3} & Business incubator contributed to an increase in my business income generation & 3.86 & 0.34 & high \\
\hline & Total & 3.79 & 0.39 & high \\
\hline
\end{tabular}

\subsection{Analytical Results}

To test the hypothesis of the study the Multiple Regression analysis, two-way analysis of variance (ANOVA) and Pearson correlation coefficient.

(H0.1): There is no significant impact at $(\alpha \leq 0.05)$ of business incubator services (Infrastructure services, business support services, networking services) on business success (revenue growth, job creation).

The results of the multiple regression analysis explained in Table 5 shows. That $\mathrm{F}=10.314$ and $\mathrm{p}$-value $=0.000$ (less than 0.05 (the level of significance)). However, the null hypothesis is rejected and the alternative hypothesis is accepted. Thus, there is a significant impact of business incubator services (Infrastructure services, business support services, networking services) on business success (revenue growth, job creation).

Based on multiple regression models, two predictor variables were found to be significant in explaining business success. The networking support services dimension had the highest influence on business success, $\beta 1=0.601$ followed by infrastructure support services, $\beta 1=0.341$. The R-squared of 0.648 means that $64.8 \%$ of the variation in business success was explained by variables.

\section{Sub hypothesis}

(H0.1.1): There is no significant impact at $(\alpha \leq 0.05)$ of business incubator services on Business revenue growth 
The results of the multiple regression analysis explained in Table 6 indicate that business incubator impact business revenue growth in JEDICO business incubators from the beneficiary perspective. Using the 0.05 level of significance, the null hypothesis is rejected and the alternative hypothesis is accepted. Based on the multiple regression models, two predictor variables were found to be significant in explaining revenue growth. The networking support services dimension had the highest influence on business success, $\beta 1=.963$ followed by infrastructure support services, $\beta 1=0.158$. The R-squared of .620 means that the variation in business success was explained by two variables. The above results showed that improving mediation and business support services components will have a positive impact on revenue growth. The value of R2 indicates that business incubators explains $79 \%$ of the variation in employment growth.

(H0.1.2): There is no statistically significant impact at $\alpha \leq 0.05$ of business incubators services on employment growth

The results of the multiple regression analysis explained in Table 7 indicated that business incubator has an impact on business success in JEDICO business incubators from the beneficiary perspective. Using the 0.05 level of significance, the null hypothesis is rejected and the alternative hypothesis is accepted. The value of R2 indicates that business incubators explains 0.74 of the variation in employment growth. Based on the multiple regression models, two predictor variables were found to be significant in explaining employment growth. The networking services dimension had the highest influence on employment growth, $\beta 1=0.880$ followed by infrastructure services, $\beta 1=0.182$. The R-squared of 0.53 means that the variation in employment growth was explained by two variables. The value of R2 indicates that business incubators explains $53 \%$ of the variation in employment growth.

Table 5. Results of multiple regression for independent variable (business incubators services) and its impact on Business success

Model Summary

\begin{tabular}{|c|c|c|c|c|}
\hline \multicolumn{5}{|c|}{ Model Summary } \\
\hline Model & $\mathrm{R}$ & R Square & Adjusted R Square & Std. Error of the Estimate \\
\hline 1 & $.805^{\mathrm{a}}$ & .648 & .603 & .26722 \\
\hline
\end{tabular}

\begin{tabular}{lllllll}
\hline ANOVA & \multicolumn{1}{l}{} \\
\hline Model & & Sum of Squares & df & Mean Square & F & Sig. \\
\hline 1 & Regression & 2.734 & 3 & .911 & 10.314 & $.000^{\mathrm{a}}$ \\
& Residual & 2.297 & 26 & .088 & &
\end{tabular}

a. Predictors: (Constant), infrastructure services, business support services, networking services.

b. Dependent Variable: business success

Coefficients

\begin{tabular}{|c|c|c|c|c|c|c|}
\hline \multirow[t]{2}{*}{ Model } & & \multicolumn{2}{|c|}{ Unstandardized Coefficients } & \multirow{2}{*}{$\begin{array}{l}\text { Standardized } \\
\text { Coefficients } \\
\text { Beta }\end{array}$} & \multirow[t]{2}{*}{$\mathrm{t}$} & \multirow[t]{2}{*}{ Sig. } \\
\hline & & B & Std. Error & & & \\
\hline \multirow[t]{4}{*}{1} & (Constant) & 1.190 & .963 & & 1.236 & .228 \\
\hline & infrastructure & .341 & .139 & .397 & 2.447 & .021 \\
\hline & Business support services & .348 & .210 & .268 & 1.656 & .110 \\
\hline & Networking services & .601 & .179 & .450 & 3.359 & .002 \\
\hline a. Depe & ent Variable: business succe & & & & & \\
\hline
\end{tabular}


Table 6. Results of Multiple Regression for independent variable (business incubators services) and its effect on revenue growth

\begin{tabular}{lllll}
\hline Model & R & R Square & Adjusted R Square & Std. Error of the Estimate \\
\hline 1 & $.889^{\mathrm{a}}$ & .791 & .765 & .21593 \\
\hline
\end{tabular}

\begin{tabular}{lllllll}
\hline ANOVA $^{\mathbf{b}}$ & \multicolumn{1}{l}{} \\
\hline Model & & Sum of Squares & df & Mean Square & F & Sig. \\
\hline 1 & Regression & 2.244 & 3 & .748 & 99.078 & $.000^{\text {a }}$ \\
& Residual & .196 & 26 & .008 & & \\
& Total & 2.440 & 29 & & &
\end{tabular}

a. Predictors: (Constant), infrastructure services, business support services, networking services.

b. Dependent Variable: revenue growth

\begin{tabular}{|c|c|c|c|c|c|c|}
\hline \multicolumn{7}{|c|}{ Coefficients $^{\mathrm{a}}$} \\
\hline \multirow[t]{2}{*}{ Model } & & \multicolumn{2}{|c|}{ Unstandardized Coefficients } & \multirow{2}{*}{$\begin{array}{l}\text { Standardized Coefficients } \\
\text { Beta }\end{array}$} & \multirow[t]{2}{*}{$\mathrm{t}$} & \multirow[t]{2}{*}{ Sig. } \\
\hline & & $\mathrm{B}$ & Std. Error & & & \\
\hline \multirow[t]{4}{*}{1} & (Constant) & .851 & .278 & & 3.066 & .005 \\
\hline & Infrastructure & .158 & .052 & 1.035 & 3.063 & .005 \\
\hline & Business support & .023 & .060 & 0.026 & .384 & .704 \\
\hline & Networking & .963 & .059 & 0.227 & 16.331 & .000 \\
\hline \multicolumn{7}{|c|}{ a. Dependent Variable: Revenue growth } \\
\hline
\end{tabular}

Table 7. Results of Multiple Regression for independent variable (business incubators services) and its impact on employment growth

\begin{tabular}{lllllll}
\hline ANOVA $^{\mathbf{b}}$ & \multicolumn{7}{l}{} \\
\hline Model & & Sum of Squares & df & Mean Square & F & Sig. \\
\hline 1 & Regression & 2.279 & 3 & .760 & 122.810 & $.000^{\mathrm{a}}$ \\
& Residual & .161 & 26 & .006 & & \\
& Total & 2.440 & 29 & & &
\end{tabular}

a. Predictors: (Constant), infrastructure services, business support services, networking services.

b. Dependent Variable: employment growth

\begin{tabular}{|c|c|c|c|c|c|c|}
\hline \multicolumn{7}{|c|}{ Coefficients $^{\mathrm{a}}$} \\
\hline \multirow[t]{2}{*}{ Model } & & \multicolumn{2}{|c|}{ Unstandardized Coefficients } & \multirow{2}{*}{$\begin{array}{l}\text { Standardized Coefficients } \\
\text { Beta }\end{array}$} & \multirow[t]{2}{*}{$\mathrm{t}$} & \multirow[t]{2}{*}{ Sig. } \\
\hline & & B & Std. Error & & & \\
\hline \multirow[t]{4}{*}{1} & (Constant) & .197 & .291 & & .676 & .505 \\
\hline & Infrastructure & .182 & .041 & 0.261 & 4.410 & .000 \\
\hline & Business support & .015 & .055 & .016 & .268 & .791 \\
\hline & Networking & .880 & .048 & 0.940 & 18.198 & .000 \\
\hline \multicolumn{7}{|c|}{ a. Dependent Variable: employment growth } \\
\hline
\end{tabular}

\section{Conclusion}

Based on the previous testing, It can be concluded that business incubator services are at high level and currently taking place at, JEDICO. Overall business incubator services are effective as they are able to improve business revenue and employment.

\section{Major conclusions of this study:}

- The study hypothesis proved that there is an impact of business incubator on business success at JEDICO business incubators. Meanwhile, mediation services and business support services are significant to business success variable. The networking support services dimension had the highest influence on business success, 
followed by infrastructure support services.

The above results demonstrated that improving networking and infrastrucure support services components will have a positive impact on business success.

- The study proved that there is an impact of business incubators service on revenue growth and job creation. The networking support services dimension had the highest influence on business success, followed byinfrastrucutre support services.

- The study proved that there is an impact of business incubators service on business job creation. The networking support services dimension had the highest influence on employment growth, $\beta 1=0.940$ followed by infrastructure services.

- Results show that perceived business incubator services practices as high level. Infrastructure support dimension indicated highest category and first rank; followed by business support services in the second rank and networking support services dimension in the third rank. The above results indicated that the respondents perceived the JEDICO business incubator components are available at high level at JEDICO business incubators. The majority of respondents agreed that the business incubators provide infrastructures, business services and networking service support at high level.

- Results show that perceived business success by beneficiary was in high category. The results for Job creation dimension indicated high category and first rank, followed by revenue growth. The above results indicated that the respondents perceived a high level of business success variable items.

- It was noted that most of the sample are male (63.3\%), the average age of respondents is from 30-39 years, $36.6 \%$ with average years of work experience ranging between $9-12$ years. Almost half of the respondents hold a diploma degree $(53.7 \%)$ and most of businesses type $(63.6 \%)$ is industrial type.

The findings are consistent with previous studies, such as: Pukite and Geipele (2015), Ozdemir and Schitoglu (2013), Al-Wadi (2013), Al-Mubarak and Busler (2013) and Barhoom (2015).

\subsection{Recommendations}

Considering the aforementioned results, the researcher recommends the following:

- JEDICO business incubators are recommended to continue their effort both in providing a high-level practice of support services and continue help firms overcome the barriers to growth during and after the development period via the different kinds of supporting mechanisms provided to them during business incubation. Finally, JEDICO business incubators are recommended to regularly assess beneficiary' perceptions and satisfactions regarding business incubators services and the level of businesses success.

\subsection{Limitations and Suggestions for Future Research}

Although research has reached its objectives, there were limitations. First, this study was limited to JEDICO business incubators as a case study, which limited the generalization of the findings. Second, this research perceived business incubators support services and business success from the beneficiary perspective. The researcher suggests other researchers focus on other measures and perceive business incubators services practices from the perspective of other stakeholders.

\section{Acknowledgments}

I would like to thank Business Incubation Officer at Jordan Enterprise Development Corporation (Miss Rawan Al Tarawneh), Human Resource Officer at Urdonia Lil Ebda (Mr. Nasser Bataineh) for facilitating the task of performing this survey. Thanks also extended to the survey respondents for their participation in the survey.

\section{References}

Al-Mubaraki, H. M., \& Busler, M. (2013). The Effect of Business Incubation in Developing Countries. European Journal of Business and Innovation Research, 1(1), 19-25.

Al-Wadi, M. (2010). The role of business incubators in economic development, with reference to the Jordanian experience. Economic and management research. Biskra University, 7, 1-20. Retrieved from file:///C:/Users/Aya/Desktop/incubatio7/alwadi.pdf.

Aridi, H. (2015). The Hashemite Kingdom of Jordan Experience in Financing Small, Medium and micro Enterprises. Jordan Enterprise Development Corporation (JEDICO). Retrieved from file:///C:/Users/Aya/Downloads/MrsHanaUraidiCEOJordanEnterpriseDevelopmentCorporationJEDCo.pdf

Badandy, O. (2018). The impact of innovation on the success of entrepreneurial enterprises in incubators at King 
Hussein Business Park. Unpublished master thesis. Amman Arab University. Jordan.

Barhoom, B. (2015). The Role of Business Incubators and Technology in Solving the Problem of Unemployment Entrepreneurs Gaza Strip. Master thesis. Islamic University. Gaza Strip. Retrieved from file://C:/Users/Aya/Downloads/114999.pdf

Cai, L., Naveed, A., Sikandar, A. Q., Asadullah, K., \& Shumaila, N. (2020). Role of Business Incubators as a Tool for Entrepreneurship Development: The Mediating and Moderating Role of Business Start-Up and Government Regulations. Sustainability, 2020, 1-24. https://doi.org/10.3390/su12051822

Carayannis, E. G., \& von Zedtwitz, M. (2005). Architecting gloCal (global-local), real-virtual incubator networks (G-RVINs) as catalysts and accelerators of entrepreneurship in transitioning and developing economies: Lessons learned and best practices from current development and business incubation practices. Technovation, 25(2), 95-110 https://doi.org/10.1016/S0166-4972(03)00072-5

Chandra, A. (2007). Approaches to Business Incubation: A Comparative Study of the United States, China and BraziL. Network financial institution at Indiana State University. https://doi.org/10.2139/ssrn.1077149

Dee, N., Gill, D., Lacher, R., Livesey, F., \& Tim, M. (2012). A review of research on the role and effectiveness of business incubation for high-growth start-ups Institute for Manufacturing. University of Cambridge Engineering Department. Retrieved from https://www.ifm.eng.cam.ac.uk/uploads/Research/CTM/Resources/12_01_dee_minshall.pdf

Duff, A. (n.d.). Best Practice in Business Incubator Management was undertaken by Andrew. AUSTEP Strategic Partnering Pty Ltd.

European Centre for Research Training and Development. (n.d.). Retrieved from file://C:/Users/Aya/Desktop/incubatio7/mubaraki.pdf

European Commission Enterprise Directorate General. (2002). Benchmarking of Business Incubators. Retrieved from file:///C:/Users/Aya/Desktop/incubatio7/New\%20folder/benchmarking_bi_part_one_2002_2346.pdf

Fadahunsi, A. (2012). The Growth of Small Businesses: Towards A Research Agenda. American Journal of Economics and Business Administration, 4(1), 105-115. https://doi.org/10.3844/ajebasp.2012.105.115

Gerlach, S. (2015). What determines a successful business incubator? Introduction to an incubator guide. $\begin{array}{lllll}\text { International Journal of Entrepreneurial Venturing, } & \text { 7(3), 286-307. }\end{array}$ https://doi.org/10.1504/IJEV.2015.071486

Getz, D., \& Carlsen, J. (2000). Characteristics and goals of family businesses in the rural tourism and hospitality sectors. Tourism Management, 21, 547-560. https://doi.org/10.1016/S0261-5177(00)00004-2

Hackett, S., \& Dilts, D. (2004). A Systematic Review of Business Incubation Research. Journal of Technology Transfer, 29, 55-82. https://doi.org/10.1023/B:JOTT.0000011181.11952.0f

Hughes, M., \& Morgan, R. E. (2007). Deconstructing the relationship between entrepreneurial orientation and business performance at the embryonic stage of firm growth. Industrial Marketing Management, 36, 651-661. https://doi.org/10.1016/j.indmarman.2006.04.003

JEDICO. (n.d.). SME Development in Jordan. Retrieved from http://worldsmeexpo.hktdc.com/pdf/2011/SeminarRoom_C/Dec_3/1630_1800_24/2_Al-Ahmad.pdf

Jordan Enterprise Development Corporation (JEDCO). (n.d.). Retrieved from http://www.jedco.gov.jo

Lewis, D. A., Harper, A. E., \& Molnar, L. A. (2011). Incubating Success Incubation Best Practice that Lead to Successful New Ventures, Michigan. University of Michigan. Retrieved from http://edaincubatortool.org/pdf/Master\%20Report_FINALDownloadPDF.pdf

Lucky, E., Olusegun, A., \& Shukri, M. (2012). Determinants of Business Success: Trust or Business Policy? Journal of Arts, Science \& Commerce, 3(3), 37-42. Retrieved from https://pdfs.semanticscholar.org/9ae5/609cc8808ead52d1b5975d014af0eca403

Niehm, L. S., Swinney, J., \& Miller, N. J. (2008). Community social responsibility and its consequences for family business performance. Journal of Small Business Management, 46(3), 331-350. https://doi.org/10.1111/j.1540-627X.2008.00247.x

Ozdamir, C. O., \& Schitoglu, Y. (2013). Assessing the Impacts of Technology Business Incubators: A framework for Technology Development Centres in Turkey. The 2nd International Conference on Leadership, Technology and Innovation Management. Procedia - Social and Behavioral Sciences, 75, 282-291. 
https://doi.org/10.1016/j.sbspro.2013.04.032

Payton, S. (2017). How to Choose a Business Incubator? Retrieved from https://smallbiztrends.com/2012/04/choose-startup-business-incub

Peters, L., Rice, M., \& Sundadarajan, M. (2004). The role of incubators in the entrepreneurial process. Journal of Technology Transfer, 29, 83-91. https://doi.org/10.1023/B:JOTT.0000011182.82350.df

Ratinho, T., Harms, R., \& Groen, A. (2009). Technology business incubators as engines of growth: Towards a distinction between technology incubators and non-technology incubators. Retrieved from https://ris.utwente.nl/ws/portalfiles/portal/6155241

Reijonen, H. (2008). Understanding the small business owner: What they really aim at and how this relates to firm performance. Management Research News, 31(8) 616-629. https://doi.org/10.1108/01409170810892172

Şehitoğlu, Z., \& Özdemir, O. C. (2013). The Impact of Business Incubation on Firm Performance during Post Graduation Period-Turkey Example. British Journal of Arts and Social Sciences, 12(1), 171-190. http://www.bjournal.co.uk/BJASS.aspx

Simpson, M., Tuck, N., \& Bellamy, S. (2004) Small Business success factors: the role of education and training. Education and Training, 46(8-9), 481-491. https://doi.org/10.1108/00400910410569605

Theodorakopoulos, N., Kakabadse, \& McGowan, C. (2014) What matters in business incubation? A literature review and a suggestion for situated theorising. Journal of Small Business and Enterprise Development, 2l(4), 602-622 https://doi.org/10.1108/JSBED-09-2014-0152

Tilana, L. (2015). The impact of business incubation in shaping the entrepreneurial mindset among incubatees. Master thesis, University of the Witwatersran. Johannesburg. Retrieved from http://wiredspace.wits.ac.za/bitstream/handle/10539/18710/L\%20Tilana\%20final\%20v1.pdf;sequence=1

UKBI. (2009). UK Incubators - Identifying Best Practice. Birmingham, UK Business Incubation Limited.

Vasily, R. (2012). Review of 20 Business Incubation Models - Hackett \&amp; Dilts Generic Business Incubator Model_2004 (Parts 12-13 of 20). Entrepreneurship, Business Incubation, Business Models \&amp; Strategy Blog. Retrieved from https://worldbusinessincubation.wordpress.com/2013/09/24/review-of-20-businessincubation-models-hacke tt-dilts-generic-business-incubator-model_2004-parts-12-13-of20/

Vilkinas, T., Cartan, G., \& Saebel, J. (2011). Business Success Factors. DKCRC Research Report 79. Ninti One Limited, Alice Springs. Retrieved from file://CC:/Users/Aya/Documents/NintiOneResearchReport_79_BusinessSuccessFactors.pdf

Walker, E., \& Brown, A. (2004). What Success Factors are Important to Small Business Owners. International Small Business Journal, 22(6). https://doi.org/10.1177/0266242604047411

Wiggins, J., \& Gibson, D. V. (2003). Overview of US incubators and the case of the Austin Technology Incubator. International Journal of Entrepreneurship and Innovation Management, 3(1/2), 56-67 https://doi.org/10.1504/IJEIM.2003.002218

\section{Copyrights}

Copyright for this article is retained by the author, with first publication rights granted to the journal.

This is an open-access article distributed under the terms and conditions of the Creative Commons Attribution license (http://creativecommons.org/licenses/by/4.0/). 